\title{
Article
}

\section{Selective Adsorption of Metal-Substituted Goethite Particles for Aqueous Solutions of Copper, Lead, and Zinc}

\author{
Takahiro KUSUYAMA, Ko TANIMURA and Kazunori SATO* \\ Department of Materials Science, Faculty of Engineering \\ Nagaoka University of Technology, Nagaoka, Niigata 940-2188, Japan \\ *Corresponding author
}

(Manuscript submitted February 15, 2003; accepted March 13, 2003)

\begin{abstract}
The substitution of foreign metals for iron in goethite $(\alpha-\mathrm{FeOOH})$ contributes to the change of adsorptive properties for metal ions, $\mathrm{Cu}^{\mathrm{II}}, \mathrm{Pb}^{\mathrm{II}}$, and $\mathrm{Zn}^{\mathrm{II}}$, in aqueous solutions. Selective removal of $\mathrm{Pb}^{\mathrm{II}}$ from low-pH solutions was enhanced by the addition of $\mathrm{Mn}$ in the synthetic process for Mn-substituted goethite particles. This enhancement was caused by the formation of specific surface sites for the selective adsorption.
\end{abstract}

\section{Introduction}

Hydrous oxides such as those of aluminum, silicon, manganese, and iron can sorb metal ions in aqueous media. Among the hydrous oxides, $\alpha-\mathrm{FeOOH}$ (goethite), is a good sorbent mineral existing in the natural environment. This property has been recognized and intensively studied, and the adsorption of metal ions onto the surface of goethite particles can be interpreted as a chemical reaction occurring at specific surface sites. These adsorption reactions at their equilibria can be thermodynamically well explained and summarized in a treatise dealing with hydrous ferric oxide (HFO) by Dzombak and Morel.[1] The hydroxyl groups on the goethite surface can uptake and release protons, resulting in a generation of surface charge due to proton transfer reactions. For goethite-particle suspensions with metal solutions, proton is the predominant surface-potential determining ion. Metal-ion adsorption on the goethite surface is therefore influenced by the solution $\mathrm{pH}$. The adsorption of heavy-metal ions generally shows S-shaped adsorption curves; with increasing the solution $\mathrm{pH}$, the adsorption onto the goethite surface increased from zero to almost $100 \%$ over a narrow $\mathrm{pH}$ range, approximately $2 \mathrm{pH}$ units, as found for heavy metals such as $\mathrm{Cu}, \mathrm{Pb}, \mathrm{Ni}, \mathrm{Co}$, and $\mathrm{Mn}$.[2] The adsorption of these metal ions as a function of $\mathrm{pH}$ differs each other.

The adsorption process used especially in the waste water treatment requires good adsorbents, which enable a selective removal of heavy-metal ions exceeding the level of their permissible concentrations in aquatic environments. Although colloidal HFO and goethite particles are capable of sorbing heavy-metal ions, coexistence of exchangeable cations and anions in the solution interferes the selective removal of heavy-metal ions. Both natural and synthetic goethites can incorporate foreign metals into their structures or precipitate metal (hydro)oxides on the goethite-particle surface. The most well-known example found in the nature is the $\mathrm{Al}$ substitution for $\mathrm{Fe}$ in the goethite structure up to about $33 \mathrm{~mol} \%$.[3] The incorporation of these foreign metals influences not only the crystallization conditions of goethite particles but also other physicochemical properties. However, 
investigation of the adsorptive property for heavy-metal ions on the synthetic goethite particles incorporating foreign metals is limited due to the inconsistency of the goethite-particle microstructure such as crystal size, surface area, and morphology. The foreign-metal substitution for $\mathrm{Fe}$ in goethite can also take place, but the solidsolubility limits of foreign-metal ions and the formation of ferrite as the second phase of metal-substituted goethites do not seem to be well known related to its synthetic process. In the present study, effects of the foreignmetal addition on the adsorptive property of goethite particles were investigated in the light of preferential removal of lead ions from an aqueous solution containing copper, lead and zinc ions. Characterization of the synthetic Mn-goethite is also presented.

\section{Experimental}

Metal $(\mathrm{X}=\mathrm{Mn}, \mathrm{La}, \mathrm{Al}, \mathrm{Cu}, \mathrm{Zn}, \mathrm{Ni}, \mathrm{Co}$, and $\mathrm{Y})$-substituted goethites, $\alpha-(\mathrm{Fe}, \mathrm{X}) \mathrm{OOH}$, were prepared by adding $\mathrm{KOH}$ to mixed solutions of $\mathrm{Fe}\left(\mathrm{NO}_{3}\right)_{3}$ and $\mathrm{X}\left(\mathrm{NO}_{3}\right)_{\mathrm{n}}$ with their appropriate proportions. To prepare these starting solutions the solvent water was repeatedly purged with an argon gas to eliminate oxygen dissolved in the water. The solution was subsequently aged at $333 \mathrm{~K}$ for $1.73 \times 10^{5}$ s to obtain $\alpha$-(Fe,X)OOH particles. The precipitates were filtered and dried in vacuum at ambient temperature for $8.64 \times 10^{4} \mathrm{~s}$. The dried sample of $1 \mathrm{~g}$ was

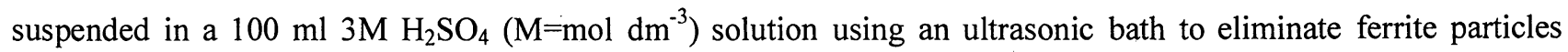
adhered to the goethite. The sample was washed with distilled water, and dried in air at $343 \mathrm{~K}$ for $8.64 \times 10^{4} \mathrm{~s}$. The concentration of $\mathrm{Fe}$ and other metal ions in the final $\alpha-(\mathrm{Fe}, \mathrm{X}) \mathrm{OOH}$ particles was determined by dissolving these particles into aqua regia and analysing the concentration of $\mathrm{Fe}$ and $\mathrm{X}$ in by atomic absorption spectrometry.

Solutions of $\mathrm{Pb}^{\mathrm{II}}, \mathrm{Cu}^{\mathrm{II}}$, and $\mathrm{Zn}^{\mathrm{II}}$ were prepared by dissolving $\mathrm{Pb}\left(\mathrm{NO}_{3}\right)_{2}, \mathrm{Cu}\left(\mathrm{NO}_{3}\right)_{2}$, and $\mathrm{Zn}\left(\mathrm{NO}_{3}\right)_{2}$ in distilled and deionized water, and $\mathrm{pH}$ of each solution was adjusted by adding a $0.05 \mathrm{M} \mathrm{NaOH}$ solution. $50 \mathrm{mg}$ of the $\alpha-(\mathrm{Fe}, \mathrm{X}) \mathrm{OOH}$ sample was suspended in $15 \mathrm{ml}$ of a $1 \mathrm{mM}$ solution containing each metal ions. The adsorption experiment was also made for a mixed solution of $\mathrm{Pb}^{\mathrm{II}}, \mathrm{Cu}^{\mathrm{II}}$, and $\mathrm{Zn}^{\mathrm{II}}$ each concentration was kept at $1 \mathrm{mM}$. The sample solution was put in a glass vial and kept at $303 \mathrm{~K}$ for $1.08 \times 10^{4} \mathrm{~s}$ in a water bath incubator, and the suspension was centrifuged at $3500 \mathrm{rpm}$ for $1.8 \times 10^{3} \mathrm{~s}$. Each supernatant solution was diluted to appropriate concentrations and analyzed for the metal ions by atomic absorption spectrometry. Phase identification for the $\alpha$ ( $\mathrm{Fe}, \mathrm{X}) \mathrm{OOH}$ samples were made by X-ray powder diffraction (XRD). Morphological observation of the $\alpha$ ( $\mathrm{Fe}, \mathrm{X}) \mathrm{OOH}$ samples was conducted using a $200 \mathrm{kV}$ transmission electron microscope (TEM). The specific surface areas of the prepared samples were determined by the BET (Brunauer, Emmett and Teller) method. Electrokinetic potential was determined by the $\mathrm{pH}$ titration.

\section{Results and Discussion}

X-ray diffraction analysis for the prepared metal-substituted goethite (Mn-, La-, Al-, Cu-, Zn-, Ni-, Co-, and Y-substituted goethites) particles revealed that the goethite lattice can incorporate these metal ions, whose amount is limited depending on the metal ions, and forms a solid solution. An incorporation of cobalt, nickel, copper, zinc, cadmium, and lead was confirmed for synthetic goethite, and the isomorphous substitution results in a distortion of the octahedral unit of the goethite structure.[4] Synthetic Mn-substituted goethite was also reported, and the possibility of the unit cell distortion in the goethite phase was discussed based on the refined lattice parameters for Mn-substituted goethite, whose solid solubility limit was approximately $14 \mathrm{~mol} \% \mathrm{Mn}$.[5]

Among the metal-substituted goethite La-substituted goethite particles exhibited the highest adsorptive ability, however, a significant amount of La was leached into the solution. In contrast, other foreign metal ions incorporated into the goethite were not detected in the solutions after the adsorption experiment. The apparent 
amount of adsorbed $\mathrm{Pb}^{\mathrm{II}}$ for Mn-substituted goethite showed the highest value among these goethite particles chemically stable in the solution at $\mathrm{pH}$. The chemical analysis by atomic absorption spectrometry revealed that the Mn concentration in Mn-substituted goethite proportionally increased with increasing ratio of manganese nitrate to ferric nitrate in the starting solution up to approximately $10 \mathrm{~mol} \% \mathrm{Mn}$. However, the $\mathrm{Mn}$ concentration in Mn-substituted goethite gradually decreased with further increase in the ratio of manganese nitrate to the starting solution. The X-ray diffraction pattern from Mn-substituted goethite particles with the composition, $\left(\mathrm{Fe}_{0.90} \mathrm{Mn}_{0.10}\right) \mathrm{OOH}$, did not reveal the existence of $\mathrm{Mn}$-ferrite, $(\mathrm{Fe}, \mathrm{Mn})_{3} \mathrm{O}_{4}$. This result indicates that $\mathrm{Mn}$ ions can be incorporated into Mn-substituted goethite particles as the lattice $\mathrm{Mn}$ ions in the framework of goethite.

Figure 1 shows variations in the $\mathrm{Pb}^{\mathrm{II}}, \mathrm{Cu}^{\mathrm{II}}$, and $\mathrm{Zn}^{\mathrm{II}}$ adsorptions onto Mn-substituted goethite particles each for the single-component metal solution with increasing $\mathrm{Mn}$ concentration. At $\mathrm{pH} 4$ the adsorbed amount of $\mathrm{Pb}^{\mathrm{II}}$ ions significantly increased particularly above approximately $5 \mathrm{~mol} \%$, but the adsorbed amounts of $\mathrm{Cu}^{\mathrm{II}}$ and $\mathrm{Zn}^{\mathrm{II}}$ ions gradually increased with increasing $\mathrm{Mn}$ concentration. At $\mathrm{pH} 6$ almost the same tendency was observed for the adsorption of $\mathrm{Pb}^{\mathrm{II}}, \mathrm{Cu}^{\mathrm{II}}$, and $\mathrm{Zn}^{\mathrm{II}}$ ions on the adsorbed amounts of these ions larger than those at $\mathrm{pH}$. The increase of the $\mathrm{Pb}^{\mathrm{II}}$ adsorption for the Mn-substituted goethite, $\alpha-\left(\mathrm{Fe}_{1-X} \mathrm{Mn}_{X}\right) \mathrm{OOH}$ ( $X$ is larger than ca. 0.05), was observed for the adsorption experiment made for the mixed solution of $\mathrm{Pb}^{\mathrm{II}}, \mathrm{Cu}^{\mathrm{II}}$, and $\mathrm{Zn}^{\mathrm{II}}$ ions, as shown in Figure 2. The affinity of heavy-metal ions for goethite generally follows the order of $\mathrm{Cu}^{\mathrm{II}}>\mathrm{Pb}^{\mathrm{II}}>\mathrm{Zn}^{\mathrm{II}}$.[2,6] The Mnsubstituted goethite exhibited a different behavior from this order; increasing amount of manganese ions into the goethite results in a preferential increase for the adsorption of $\mathrm{Pb}^{\mathrm{II}}$ ions. Figure 1 (a) showed the order, $\mathrm{Pb}^{\mathrm{II}}>\mathrm{Cu}^{\mathrm{II}}$ $>\mathrm{Zn}^{\mathrm{II}}$ for the $\alpha-\left(\mathrm{Fe}_{0.9} \mathrm{Mn}_{0.1}\right) \mathrm{OOH}$ particles. The specific surface area, $S_{\mathrm{A}}$, of $\alpha-\left(\mathrm{Fe}_{1-X} \mathrm{Mn}_{X}\right) \mathrm{OOH}$ particles slightly decreased with an increase of $X ; S_{\mathrm{A}}=34.2 \mathrm{~m}^{2} / \mathrm{g}$ at $X=0, S_{\mathrm{A}}=35.2 \mathrm{~m}^{2} / \mathrm{g}$ at $X=0.05, S_{\mathrm{A}}=31.0 \mathrm{~m}^{2} / \mathrm{g}$ at $X=0.075$, and $S_{\mathrm{A}}=28.5 \mathrm{~m}^{2} / \mathrm{g}$ at $X=0.10$. The TEM observation revealed that the needle-shaped feature did not change but the thickness of the particles slightly increased with $X$. Crystallographic domain size of Mn-substituted goethite particles was estimated to increase with $X$ due to the sharpening of hk0 X-ray reflection lines.[7] Although the
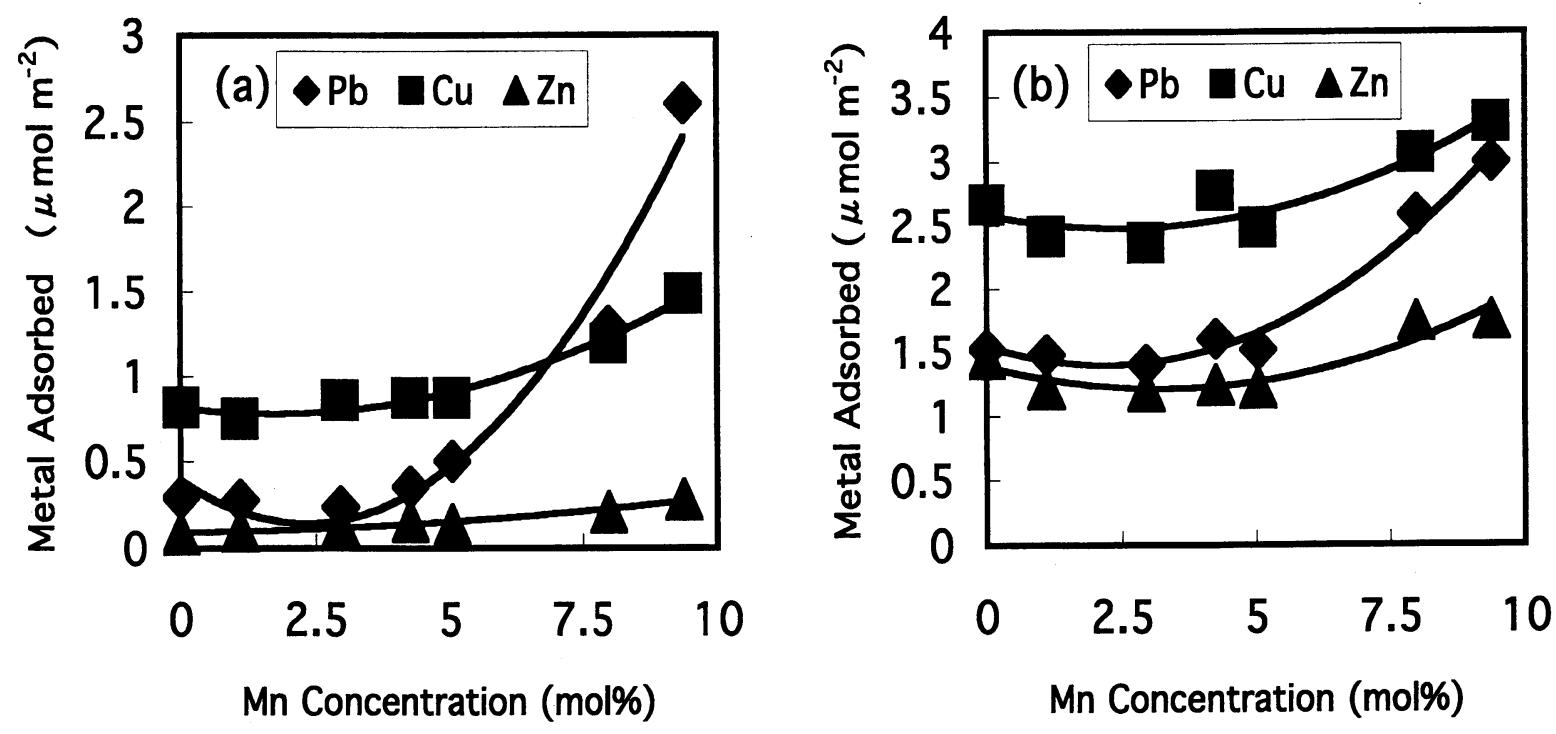

Fig 1. The amounts of $\mathrm{Pb}^{\mathrm{II}}, \mathrm{Cu}^{\mathrm{II}}$, and $\mathrm{Zn}^{\mathrm{II}}$ adsorbed onto Mn-substituted goethites as a function of the Mn concentration. (a) pH 4 and (b) pH 6 each for single-component solutions. 
valency of the Mn in Mn-substituted goethite is not known, unit-cell dimensions determined by X-ray diffraction [4] and an elemental spot analysis by analytical electron microscopy [8] suggest an inhomogeneous substitution of manganese for iron in the goethite structure. These crystallographic structural changes can result in a formation of specific adsorption sites by the incorporation of manganese ions into the goethite lattice.

Hydrous iron oxide, being more acidic than hydrous manganese oxide, can adsorb more amounts of cations by the ion exchange reaction at the same $\mathrm{pH}$ than does hydrous manganese oxide.[9,10] Since distinct

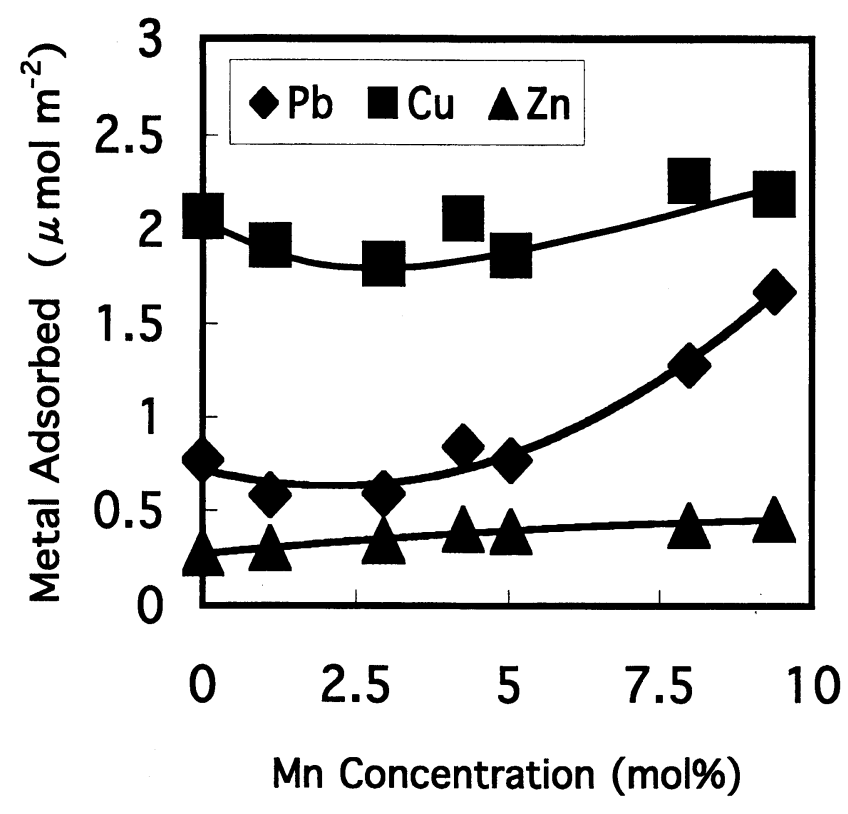

Fig 2. The amounts of $\mathrm{Pb}^{\mathrm{II}}, \mathrm{Cu}^{\mathrm{II}}$, and $\mathrm{Zn}^{\mathrm{II}}$ adsorbed at $\mathrm{pH} 6$ as a function of the Mn concentration for the coexistence of $\mathrm{Pb}^{\mathrm{II}}, \mathrm{Cu}^{\mathrm{II}}$, and $\mathrm{Zn}^{\mathrm{II}}$ ions in the solution. types of sites on an oxide surface have been proposed to be responsible for different metal-ion affinities,[11] the incorporation of $\mathrm{Mn}$ into the goethite lattice could account for the preferential increase of the $\mathrm{Pb}^{\mathrm{II}}$ adsorption within the solid solubility limit of $\mathrm{Mn}$ in goethite. However, crystallographic surface sites for the adsorbateadsorbent linkage on the goethite surface have not been determined so far. The effect of foreign metal incorporation into goethite on the metal-ion adsorptive properties cannot be explained by the shift of the point of zero charge (PZC), since the PZC values for the samples, $\left(\mathrm{Fe}_{1-X} \mathrm{Mn}_{X}\right) \mathrm{OOH}$ with $X=0$ was pH $5.4, X=0.05$ was $\mathrm{pH} 6.9$, and $X=0.1$ was $\mathrm{pH}$ 7.0. Although the surface charge greatly affects the adsorptive behavior of hydrous oxides, the significant increase of the $\mathrm{Pb}^{\mathrm{II}}$ adsorption occurred for the Mn-substituted goethite with its Mn

concentration higher than ca. 5 mol\%. Formation of specific surface sites most likely explain the preferential adsorption of lead ions observed in the present results.

\section{References}

1) D. A. Dzombak and F. M. M. Morel, Surface Complexation Modeling, Hydrous Ferric Oxide, John Wiley \& Sons, New York, USA, (1990), pp.89-102.

2) B. R. Coughlin and A. T. Stone, Envirn. Sci. and Technol., 29, 2445-2455 (1995).

3) C. W. Correns and W. von Engelhardt, Nachr. Akad. Wiss. Gottingen. Math.-Phys., 213, 131-137 (1953).

4) J. Gerth, Geochim. Cosmochim. Acta, 56, 363-371 (1990).

5) E. E. Sileo, M. Alvarez and E. H. Rueda, Int. J. Inorg. Mater., 3, 271-279 (2001).

6) U. Schwertman and R. M. Taylor, "Iron oxide" Minerals in soil environments, SSSA Book Series No. 1, Soil Science of America, Madison, Wisconsin, USA (1989), pp.379-427.

7) W. Stiers and U. Schwertmann, Geochim. Cosmochim. Acta, 7, 1909-1911 (1985).

8) U. G. Gasser, R. Nuesch, M. J. Singer and E. Jeanroy, Clay Minerals, 34, 291-299 (1999).

9) A. Clearfield, Chem. Rev. 88(1988)125-148.

10) A. Clearfield, Inorganic Ion Exchange Materials, CRC Press, Boca Raton, Florida, USA, (1982), pp.191-197.

11) M. M. Benjamin and J. O. Leckie, J. Colloid and Interface Sci., 79, 209-221 (1981). 